\title{
Patient Dose Estimation Using CT-Expo Software at Two Hospitals in North-Central Nigeria
}

\author{
Mary-ann Etim Ekpo, 줄 Rachel Ibhade Obed, ${ }^{1}$ (1) Akintayo Daniel Omojola²
}

'Department of Physics, University of Ibadan, Ibadan, Oyo State, Nigeria

${ }^{2}$ Department of Radiology, Medical Physics Unit, Federal Medical Centre Asaba, Delta State, Nigeria

Submitted: 04.06.2018 Accepted: 11.07.2018

Correspondence: Mary-ann Etim Ekpo, Department of Physics, University of Ibadan, Ibadan, Oyo State, Nigeria E-mail: ekammaekpo84@gmail.com

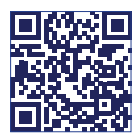

Keywords: Computed tomography; dose length product; effective dose; organ dose; volume computed tomography dose index.

\begin{abstract}
Objective: Simulation software has aided the estimation of organ dose from computed tomography (CT) examinations. The aim of this study was to use the CT-Expo (SASCRAD, Fritz-Reuter-Weg, Buchholz, Germany) software to determine volume CT dose index $\left(C T D I_{\text {vol }}\right)$, dose length product (DLP), organ dose and effective dose.
\end{abstract}

Methods: A total of I7I patient data were retrieved from a Toshiba Aquillion 16-slice CT scanner (Toshiba Corp., Tokyo, Japan) representing CT unit A and a Philips Brilliance 16-slice CT scanner (Koninklijke Philips N.V., Amsterdam, Netherlands) representing CT unit B and a CT-Expo spreadsheet was used to estimate the dose delivered.

Results: Head CT scans were the most frequently seen (64\%) at the 2 facilities studied. The CT parameters of peak kilovoltage $\left(k V_{p}\right)$ and pitch between the 2 units were statistically different $(p<0.05)$. There was no significant difference in $C T D I_{\text {vol }}$ between $C T$ unit $A$ and $B(p=0.199)$. A comparison of $C T D I_{v o l}$ and DLP of CT units $A$ and $B$ with other studies revealed no statistically significant difference $(p<0.05)$. The mean effective dose $(E)$ for the abdomen was greater compared with other studies, but without a statistically significant difference $(p<0.05)$. Furthermore, no significant difference in organ dose was seen between $C T$ units $A$ and $B(p=0.677)$. $A$ comparison of organ dose with other studies indicated no relevant difference $(p<0.05)$.

Conclusion: The CT-Expo software showed good results with the imPACT software (ImPACT scanner evaluation group, London, UK). CT unit A had greater differences in $C T D I_{\text {vol }}$ and DLP compared with unit $B$. This difference could be associated with the significant difference seen in the $k V_{p}$ and pitch of both scanners.

\section{INTRODUCTION}

lonizing radiation is capable of causing cell death or radiation-induced reproductive failure, which can lead to changes in the genes involved in cell growth, loss of normal nuclear structure, degradation of DNA and carcinogenesis. ${ }^{[1-3]}$ Despite its ability to completely alter or change genetic structure, it is indispensable to modern medicine for diagnosis and treatment. Medical practice involving ionizing radiation includes diagnostic examinations, interventional procedures, and radiotherapy treatments typically undertaken in a radiology, nuclear medicine, or radiation oncology department or clinic. Globally, it is estimated that approximately 3.6 billion diagnostic examinations and 6 million therapeutic treatments are performed annually. [4] Primarily, the people exposed to ionizing radiation for medical purposes are the patients themselves. These exposure situations are deliberate and voluntary with some diagnostic or therapeutic health benefits to be gained. Recent figures show that diagnostic medical exposures, including radiology and nuclear medicine, account for about one-fifth of the average annual output dose to the global population from all sources. ${ }^{[5]}$

The radiation effects associated with ionizing radiation can be classified as either deterministic (effect of radiation has a threshold to cause damage) or stochastic (no radi- 
ation threshold is necessary to cause damage). There is irrefutable evidence from epidemiological studies that ionizing radiation exposure at high doses is associated with an increase in cancer incidence and morbidity. ${ }^{[6]}$ To accurately evaluate the associated radiation-induced risks, knowledge of doses to the specific region or organ is recommended in the determination of the probability of inducing any deterministic effects or corresponding stochastic risk of carcinogenesis and genetic effects. ${ }^{[7,8]}$

Among diagnostic modalities, computed tomography (CT) is the greatest contributor to population dose, although it accounts for a much smaller proportion of the total number of examinations. Optimizing patients' procedures, and maintaining good practice is a priority for all diagnostic radiological examinations, including $\mathrm{CT}$ examinations. The risk is greater for children, who are more radiosensitive than adults. ${ }^{[9]}$

Since its launch into clinical practice as a scanning technology more than 40 years ago, CT has developed and advanced, and its use has become more widespread. However, concerns over patient radiation dose risk from CT scans have grown, and the introduction of multi-slice scanners has focused further attention on this issue. ${ }^{[10,11]}$ In 2007, the International Commission on Radiological Protection (ICRP) provided the Diagnostic Reference Levels (DRL) to be used in medical diagnosis for the management and evaluation of CT dose quantities and for identification of unusually high doses. The DRL is not a limitation of diagnostic radiation dose or a reference for organ doses, but provides quantities to compare protocols, promote optimization, and avoid unnecessary doses.

In Nigeria, large radiation doses to patients were observed in ordinary X-ray exposures, and large variations in the radiation dose were also observed both within and between hospitals. It is therefore likely that similar situations exist with CT. Records of radiation doses from CT exams in Nigeria and the harmonization of CT protocols and dose reference levels have not been established due to poor implementation of regulatory policies and monitoring, but there is evidence of a proliferation of CT facilities in the country. ${ }^{[1,12]}$ The need to add consideration of organ dose tolerance in relation to dose optimization by reviewing CT protocols has now become even more pertinent, since organ doses to patients undergoing $\mathrm{CT}$ examinations are generally much higher than those associated with conventional, mammography and fluoroscopy examinations.

This study was intended to determine the radiation dose delivered to adult patients during CT examination at 2 hospitals (radiology department) in North-Central Nigeria using CT-Expo software, which is a representation of a hermaphrodite mathematical model. The CT dose parameters to be determined were the volume CT dose index $\left(C T D I_{\text {vol }}\right)$, dose length product (DLP), effective dose $(E)$, and specific organ dose, and the aim was to compare the results with other relevant studies.

\section{MATERIAL AND METHODS}

A 6-month retrospective study of CT scans of adult patients at the diagnostic radiology departments of 2 tertiary hospitals in North-Central Nigeria were recorded during the period from October 2016 to March 2017. A total of $17 \mid$ adult cases were selected and the details were recorded. Demographic information (age and sex) of the patients were noted to ensure that only adult patients were included in the study. The examinations under review were routine, non-contrast CT scans of the head, chest, and abdomen.

The hospitals in the study passed a quality control test. The type and specification of the device in use at each unit was Toshiba Aquillion 16-slice scanner (Toshiba, Corp., Tokyo, Japan) (Hospital A) and Philips Brilliance 16-slice (Koninklijke Philips N.V., Amsterdam, Netherlands) (Hospital B). To calculate the organ dose and $E$, the scan parameters of the Digital Imaging and Communications in Medicine (DICOM) headers were used: tube current, tube voltage, scan length, pitch, beam collimation, table feed, rotation time, and slice thickness for each patient selected. These parameters were recorded on a separate data sheet.

Patient organ dose evaluation was performed using CTExpo software (version 2.3; SASCRAD, Fritz-Reuter-Weg, Buchholz, Germany) an MS-Excel application written in Visual Basic for the calculation of patient dose in CT examinations. It is based on computational methods used to evaluate the data collected in German surveys on CT exposure practice in both 1999 and 2002. The software allows for the calculation of the following dose quantities:

- Weighted CTDI

- Volume CTDI

- Dose length product

- Organ doses

- Effective dose (according to ICRP 60 and 103)

In contrast to similar programs for CT dose calculations, CT-Expo offers the user a number of unique features, such as: $^{[13]}$

a) Dose calculations for all age groups (adults, children, neonates)

b) Dose calculations for each gender

c) Dose calculations for all existing scanner models

d) Correction of scanner-specific influences

e) Correction of over-beaming effects

f) Correction of over-ranging effects in spiral mode 


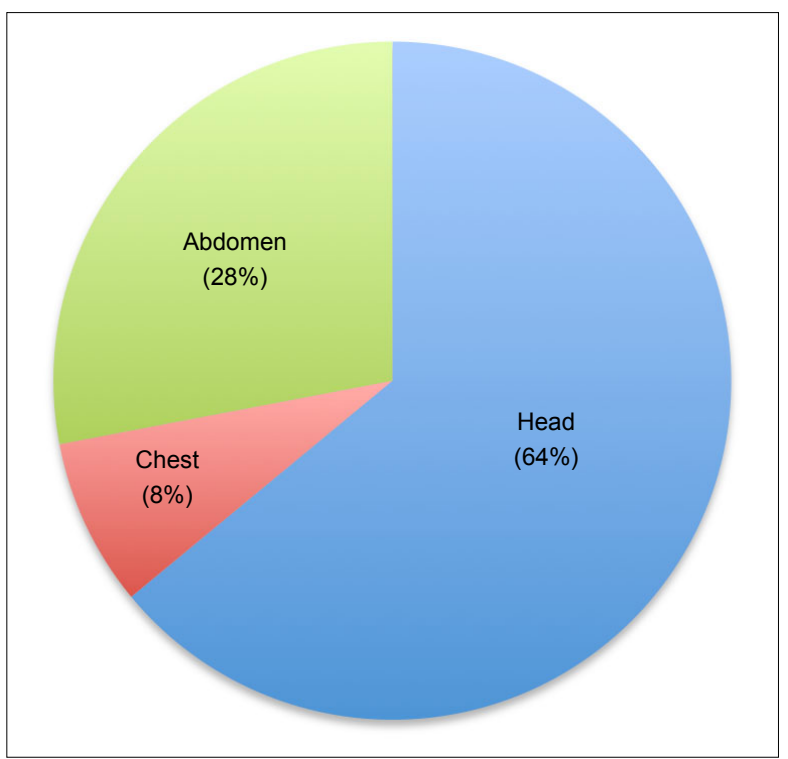

Figure 1. Distribution of patients for each type of examination.

g) Free and standardized dose assessment from scan parameters as well as from dose data provided by the scanner

h) Assessment of dose contribution resulting from scan projection radiographs

Table I. Mean scan parameters of examinations

\begin{tabular}{lccccc}
\hline Examination & $\begin{array}{c}\text { CT } \\
\text { unit }\end{array}$ & mAs & kVp & $\begin{array}{c}\text { Scan length } \\
(\mathbf{c m})\end{array}$ & Pitch \\
\hline Head & A & 200 & 118 & 16.8 & 0.6 \\
& B & 124 & 120 & 21.4 & 0.3 \\
Chest & A & 74 & 116 & 32.6 & 1.2 \\
& B & 141 & 120 & 63.8 & 0.2 \\
Abdomen & A & 112 & 116 & 40.1 & 0.8 \\
& B & 196 & 120 & 47.3 & 0.2 \\
\hline
\end{tabular}

$\mathrm{CT}$ : Computed tomography; $\mathrm{k} \mathrm{V}_{\mathrm{p}}$ : peak kilovoltage; $\mathrm{mAs:}$ milliampere seconds. i) Comparison with results from the German CT survey

j) A comprehensive benchmark functions including guidance on dose optimisation.

The scans of body parts examined were matched to phantoms, with the start and end of scans defined as from the top of the head through to the base of the skull for a head scan, from the clavicles through the base of the lungs for a chest scan, and from the top of the liver to the top of the pubic symphysis for an abdomen scan. Exam-technique parameters were used to estimate organ doses. The results of organ dose and $E$ using tissue weighting factors from ICRP publication no. 103 were recorded..$^{[14]}$

\section{Statistical analysis}

The data analysis was performed using SPSS for Windows, Version 16.0 (SSPSS Inc., Chicago, IL, USA). Descriptive statistics, the one-sample t-test, and the independent sample $\mathrm{t}$-test were used at a $95 \%$ level of significance. $\mathrm{P}<0.05$ was considered statistically significant.

\section{RESULTS}

The distribution of head (64\%), chest (8\%), and abdomen (28) examinations performed for the I7I patients who underwent CT procedures in the 2 teaching hospital radiology CT units located in North-Central Nigeria in the study is demonstrated in a pie chart in Figure I.

Assessment of the scan parameters of the $2 \mathrm{CT}$ units revealed no statistically significant difference in $\mathrm{mAs}$ (milliampere seconds) $(p=0.594)$ or scan length $(p=0.368)$; however, differences were seen in peak kilovoltage $(k V p)$ $p=0.007)$ and pitch $(p=0.024)$ in the 3 body regions (Table I).

The CTDI ${ }_{\text {vol }}$ at the $75^{\text {th }}$ percentile for CT unit A for the head, chest, and abdomen were 140, 19, and I $12.63 \mathrm{mGy}$, respectively. Similarly, for unit $B$, for the head, chest, and abdomen, the finding were 60.9, 10.6, and $15.5 \mathrm{mGy}$, respectively. An independent sample t-test indicated no significant difference in the CTDI ${ }_{\text {vol }}$ at the $75^{\text {th }}$ per-

Table 2. Comparison of volume CT dose index in this study and other studies at the $75^{\text {th }}$ percentile

\begin{tabular}{|c|c|c|c|c|c|c|c|c|c|}
\hline Region & CT unit & This study & EC & USA & Ireland & Switzerland & Germany & Kenya & Nigeria \\
\hline \multirow[t]{2}{*}{ Head } & A & 140 & 60 & 57 & 58 & 65 & 65 & 61 & 61 \\
\hline & B & 60.9 & & & & & & & \\
\hline \multirow[t]{2}{*}{ Chest } & A & 19 & 30 & 15 & II & 10 & 12 & 19 & 17 \\
\hline & B & 10.6 & & & & & & & \\
\hline \multirow[t]{2}{*}{ Abdomen } & $A$ & 112.63 & 35 & 20 & 12 & 15 & 20 & 20 & 20 \\
\hline & B & 15.5 & & & & & & & \\
\hline
\end{tabular}


centile $(p=0.199)$. The results of a comparison of this study's $C T D I_{\text {vol }}$ at the $75^{\text {th }}$ percentile for $C T$ unit $A$ with the European Commission states (EC) $(p=0.266),{ }^{[15]}$ the USA $(p=0.199),{ }^{[16]}$ Ireland $(p=0.185),{ }^{[17]}$ Switzerland $(p=0.210),{ }^{[18]}$ Germany $(p=0.221),{ }^{[19]}$ Kenya $(p=0.218),{ }^{[20]}$ and Nigeria $(p=0.215)^{[21]}$ was not significant. The comparison of the $C T D I_{\text {vol }}$ at the $75^{\text {th }}$ percentile for $C T$ unit $B$ with the EC group $(p=0.531)$, the USA $(p=0.940)$, Ireland $(p=0.933)$, Switzerland $(p=0.968)$, Germany $(p=0.892)$, Kenya $(p=0.848)$, and Nigeria $(p=0.872)$ also yielded no statistically significant difference (Table 2 ).
The DLP at the $75^{\text {th }}$ percentile for CT unit A for the head, chest, and abdomen were 2687.2, 734.8, and $2152.35 \mathrm{mGy}$. $\mathrm{cm}$, respectively. Similarly, CT unit B results for the head, chest, and abdomen were II4I.73, 458.3, and 685.73 $\mathrm{mGy} . \mathrm{cm}$, respectively. An independent sample t-test revealed no significant difference in the DLP at the $75^{\text {th }}$ percentile $(p=0.150)$. Comparison of this study's DLP at $75^{\text {th }}$ percentile for CT unit $A$ with the EC group $(p=0.138)$, the USA $(p=0.17 \mid)$, Ireland $(p=0.083)$, Switzerland $(p=0.125)$, Germany $(p=0.143)$, Kenya $(p=0.563)$, and Nigeria $(p=0.337)$ was not significant. In addition, a comparison

Table 3. Comparison of dose length product in this study and other studies at the $75^{\text {th }}$ percentile

\begin{tabular}{lccccccccc}
\hline Region & CT unit & This study & EC & USA & Ireland & Switzerland & Germany & Kenya & Nigeria \\
\hline Head & A & 2687.2 & 1000 & 1011 & 540 & 1000 & 950 & 1612 & 1310 \\
& B & 1141.73 & & & & & & & \\
Chest & A & 734.8 & 400 & 545 & 390 & 400 & 400 & 895 & 735 \\
& B & 458.3 & & & & & & 1800 & 1842 \\
Abdomen & A & 2152.35 & 800 & 1004 & 600 & 650 & & 1486 \\
& B & 685.73 & & & & & & & \\
\hline
\end{tabular}

All measurements in mGy. CT: Computed tomography; EC: European Commission states.

Table 4. Comparison of CT-Expo software results for this study with other related studies using imPACT software

\begin{tabular}{lccccccc}
\hline Organ & This study (CT unit A) & This study (CT unit B) & Nigeria & Turkey & Tanzania & UK & Japan \\
\hline Brain & 53.2 & 97.6 & 27.87 & 37 & 63.9 & - & - \\
Eye lens & 87.4 & 126.9 & 55 & 45 & 31.5 & - & 22.4 \\
RBM & 11.5 & 11.3 & - & - & 3.5 & 2.7 & 1.5 \\
Skin & 9.9 & 6.2 & - & - & - & - & - \\
Breast & 31.4 & 17.3 & 26.41 & - & 26.1 & 21.4 & 15.9 \\
Lung & 19.1 & 18.7 & 30.63 & 33 & 7 & 22.4 & 19.6 \\
Thyroid & 13.1 & 15.6 & 10.21 & 51 & 12.3 & 2.3 & 0.6 \\
Skin & 4.9 & 5.4 & - & - & - & - & - \\
Liver & 83.8 & 24.1 & 33.06 & 13 & 34.1 & 20.4 & 27.8 \\
Stomach & 84.9 & 24.6 & 34 & - & 35.6 & 22.2 & 26.9 \\
Ovary & 18.6 & 10.5 & - & - & 24 & 22.7 & 15.1 \\
Skin & 21.9 & 7.6 & - & - & - & -
\end{tabular}

Table 5. Comparison of effective dose with similar studies

\begin{tabular}{|c|c|c|c|c|c|c|c|c|}
\hline Body region & This study & Osei \& Darko & Clarke et al. & Tsai et al. & Origgi et al. & Aldrich et al. & EC & UK \\
\hline Head & 6.6 & 1.8 & 1.3 & 1.6 & 1.8 & 2.8 & 2.0 & 1.5 \\
\hline Chest & 8.2 & 7.9 & 5.6 & 8.4 & 7.9 & 9.3 & 8.8 & 5.8 \\
\hline Abdomen & 24.9 & - & 5.8 & 7.4 & 7.9 & 10.1 & 9.0 & 5.3 \\
\hline
\end{tabular}




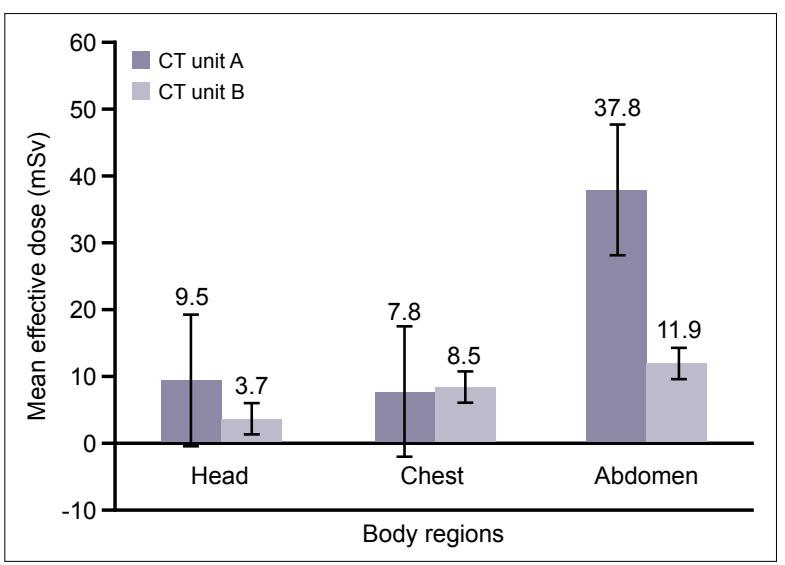

Figure 2. Mean effective computed tomography dose.

of this study's DLP at the $75^{\text {th }}$ percentile for CT unit B with EC members $(p=0.920)$, the USA $(p=0.736)$, Ireland $(p=0.297)$, Switzerland $(p=0.782)$, Germany $(p=0.967)$, Kenya $(p=0.120)$, and Nigeria $(p=0.243)$ revealed no statistically significant difference (Table 3 ).

Furthermore, comparison of the organ dose to the head (brain, eye lens, red bone marrow, and skin), chest (breast, lung, thyroid, and skin), and abdomen (liver, stomach, ovaries, and skin) between the $2 \mathrm{CT}$ units were not statistically different $(p=0.677)$. There were no difference in mean dose for $C T$ unit $A$ and studies conducted in Nigeria $(p=0.120),{ }^{[2]}$ Turkey $(p=0.385),{ }^{[23]}$ Tanzania $(p=0.163),{ }^{[24]}$ the UK $(p=0.125),{ }^{[25]}$ and Japan $(p=0.05 I) \cdot{ }^{[26]}$ Similarly no significant differences were seen for $C T$ unit $B$ and studies conducted in Turkey $(p=0.414)$, Tanzania $(p=0.447)$, Nigeria $(p=0.610)$, the UK $(p=0.788)$, and Japan $(p=0.172)$ (Table 4).

The mean $E$ value from both scanners is presented in a graph (Fig. 2). The mean $E$ delivered by $C T$ unit $A$ to the head, chest, and abdomen was 9.5, 7.8, and $37.8 \mathrm{mSv}$, respectively, and for CT unit B, the results were $3.7,8.5$, and $11.9 \mathrm{mSv}$, respectively. There was no statistically significant result in either case $(p=0.360)$ (Table 5).

\section{DISCUSSION}

The CTDI ${ }_{\text {vol }}$ at the $75^{\text {th }}$ percentile for CT unit A showed the greatest difference in scans of the head, when compared with other studies. It was $80 \%$ higher than that reported for the EC, $84.3 \%$ higher than seen in the USA, 82\% higher than Ireland, $73.2 \%$ higher than Switzerland and Germany, and $78 \%$ higher than that reported in Kenya and Nigeria. This difference could largely be as a result of the $k V_{p}$ and pitch used, as well as the type of scanner used. The difference in $C T D I_{\text {vol }}$ at the $75^{\text {th }}$ percentile between CT unit $\mathrm{B}$ for the head and other studies was below $7 \%$.

The CTDI ${ }_{\text {vol }}$ at the $75^{\text {th }}$ percentile for CT unit A for the chest was higher compared with studies conducted in the USA (23.5\%), Ireland (53.3\%) Switzerland (62.1\%), Ger- many (45.2\%), and Nigeria (1 $1.1 \%$ ), but was the same as that reported in Kenya. The CTDI ${ }_{\text {vol }}$ at the $75^{\text {th }}$ percentile for $C T$ unit $B$ for the chest was lower than that seen in the EU (95.6\%), the USA (34.4\%), Ireland (3.7\%), Germany (12.4\%), Kenya $(56.8 \%)$, and Nigeria $(46.4 \%)$, but was higher than the results from Switzerland (5.8\%), with the least difference seen in a comparison with Ireland.

The CTDI ${ }_{\text {vol }}$ at the $75^{\text {th }}$ percentile for CT unit $A$ for the abdomen was highest when contrasting with the EC (105.2\%), the USA (139.7\%), Ireland (161.5\%), Switzerland (153\%), Germany (139.7\%), Kenya (139.7\%), and Nigeria (I39.7\%). The abdomen had the highest percentage of difference in $\mathrm{CTDI}_{\text {vol }}$. The percentage of difference for CTDlvol at the $75^{\text {th }}$ percentile for CT unit B for the abdomen was lower compared to the EC, the USA, Germany, Kenya, and Nigeria, but was higher than that seen in Ireland (25.5\%) and Switzerland (3.3\%).

The DLP at the $75^{\text {th }}$ percentile for CT unit A for the head was quite a bit higher than that of the EC, the USA, Ireland, Switzerland, Germany, Kenya, or Nigeria. The DLP at the $75^{\text {th }}$ percentile for $C T$ unit $B$ for the head was lower in this study than previously reported values in Kenya and Nigeria. The percentage of difference between CT unit $A$ and $B$ was $80.7 \%$. The chest DLP in CT unit $A$ was similar in value to the results of another study conducted in Nigeria, but was higher than other studies conducting similar research. The DLP for the chest in CT unit B had the greatest difference when compared with research conducted in Kenya (64.5\%). The DLP for the abdomen for CT unit A was greater than the other studies used, but the CT unit $B$ abdomen DLP value was significantly lower compared with that of the $E C$ group, the USA, Germany, Kenya, and Nigeria.

The CT-Expo results showed no difference in organ dose between $C T$ units $A$ and $B$. The CT-Expo software results for this study were also compared with the imPACT dosimetric calculator (ImPACT scanner evaluation group, London, UK), and the results obtained revealed no difference between our study and research conducted in Nigeria (Akpochafor et al.), Turkey (Cakmak et al.), Tanzania (Ngaile et al.), UK (Shrimpton et al.) and Japan (Nishizawa et al.).

The mean difference in $\mathrm{E}$ to the head for both $\mathrm{CT}$ units was highest compared to Osei and Darko (114.3\%), ${ }^{[27]}$ Clarke et al. (134.2\%), ${ }^{[2]}$ Tsai (I22\%), ${ }^{[29]}$ Origgi et al. (I 14.3\%),, Aldrich et al. (80.9\%), ${ }^{[3]}$ an EC group $(107 \%)^{[32]}$ and the UK $(126 \%){ }^{[33]}$ The $E$ to the chest in this study was less than that reported by Tsai et al., Aldrich et al., and the EC group. However, the mean $\mathrm{E}$ to the abdomen was higher than other values studied.

\section{CONCLUSION}

The CT-Expo software was a good tool for accessing patient doses in the 2 facilities studied (CT units $A$ and $B$ ). 
The CTDI ${ }_{\text {vol }}$ and DLP for CT unit $A$ to the head and abdomen were higher than those of $\mathrm{CT}$ unit $\mathrm{B}$, and were also the highest when compared with other studies, although these differences were not statistically significant when compared with other studies. CT unit B results were consistent with other studies, suggesting that the $C T$ unit $B$ protocol might be useful to CT unit $A$ in achieving dose optimization. Nevertheless, it is important to remember that dose discrepancies may have been greatly affected by $k V_{p}$ and pitch, which were statistically significant in this study.

\section{Acknowledgment}

The authors wish to acknowledge the support of the International Centre for Theoretical Physics (ICTP), TriesteItaly and the International Atomic Energy Agency (IAEA) for the training of the authors under the STEP fellowship program, and the assistance of the radiographers of the radiology departments of both participating hospitals for their corporation in data collection during the exercise.

Informed Consent

\section{Retrospective study.}

Peer-review

Internally peer-reviewed.

Authorship Contributions

Concept: R.I.O., M.E.E.; Design: R.I.O., M.E.E.; Data collection \&/or processing: R.I.O., M.E.E., A.D.O.; Analysis and/ or interpretation: R.I.O., M.E.E., A.D.O.; Literature search: R.I.O., M.E.E., A.D.O.; Writing: R.I.O., M.E.E., A.D.O.; Critical review: R.I.O., A.D.O.

Conflict of Interest

None declared.

\section{REFERENCES}

1. Shah DJ, Sachs RK, Wilson DJ. Radiation-induced cancer: a modern view. Br J Radiol 2012;85:e1166-73. [CrossRef]

2. Reisz JA, Bansal N, Qian J, Zhao W, Furdui CM. Effects of ionizing radiation on biological molecules-mechanisms of damage and emerging methods of detection. Antioxid Redox Signal 2014;21:260-92.

3. Gilbert ES. Ionising radiation and cancer risks: what have we learned from epidemiology? Int J Radiat Biol 2009;85:467-82. [CrossRef]

4. United Nations Scientific Committee on the Effects of Atomic Radiation. Report of the United Nations Scientific Committee on the Effects of Atomic Radiation 2010 Fifty-seventh session, includes Scientific Report: summary of low-dose radiation effects on health. Vienna: United Nations; 2011. Available at: http://www.unscear.org/ docs/publications/2010/UNSCEAR_2010_Report.pdf. Accessed Jul 13, 2018.

5. International Commission on Radiological Protection. The 2007 Recommendations of the International Commission on Radiological Protection. ICRP publication 103. Exeter: Elisevier; 2007. Available at: http://journals.sagepub.com/doi/pdf/10.1177/ANIB_37_2-4. Accessed Jul 13, 2018.
6. Valentin J; International Commission on Radiation Protection. Managing patient dose in multi-detector computed tomography(MDCT). ICRP Publication 102. Ann ICRP 2007;37:1-79, iii.

7. Valentin J. Low-dose extrapolation of radiation-related cancer risk. Ann ICRP 2005;35:1-140. [CrossRef]

8. United Nations Scientific Committee on the Effects of Atomic Radiation. UNSCEAR 2013 Report to the General Assembly, with scientific annexes. Vol. I,II. United Nations; 2014.

9. International Commission on Radiological Protection. 1990 Recommendations of the International Commission on Radiological Protection. Ann ICRP 1991;21:1-201.

10. National Council on Radiation Protection and Measurements (NCRP). Reference levels and Achievable Doses in Medical and Dental Imaging: Recommendations for the United States. Report No. 172. Bethesda: NCRP Publication; 2002.

11. Akpochafor MO, Omojola AD, Soyebi KO, Adeneye SO, Aweda MA, Ajayi HB. Assessment of peak kilovoltage accuracy in ten selected X-ray centers in Lagos metropolis, South-Western Nigeria: A quality control test to determine energy output accuracy of an X-ray generator. Journal of Health Research and Reviews 2016;3:60-5.

12. Chiegwu HU, Bessie EI, Chukwuemeka NC, Ike OSO, Emejulu OA, Chimuanya UD. Increasing radiation doses from computed tomography versus diagnostic reference levels: How compliance are we? BJMMR 2015;9:1-15. [CrossRef]

13. Stmm G, Nagel HD. CT-Expo V 2.3 A Tool for Dose Evaluation in Computed Tomography User's Guide. 2014. Available at: http://edu. hioa.no/MABIO5000/CT-Expo\%20Manual\%20(E)\%20V2.3.pdf. Accessed Jul 13,2018.

14. Ding A, Gao Y, Liu H, Caracappa PF, Long DJ, Bolch WE, et al. Virtual Dose: a software for reporting organ doses from CT for adult and pediatric patients. Phys Med Biol 2015;60:5601-25. [CrossRef]

15. European Commission. Radiation Protection $N^{\circ} 180$. Medical Radiation Exposure of the European Population. Luxemburg: Publications Office of the European Union; 2014. Available at: https://ec.europa.eu/energy/sites/ener/files/documents/RP180.pdf. Accessed Jul 13, 2018 .

16. Kanal KM, Butler PF, Sengupta D, Bhargavan-Chatfield M, Coombs LP, Morin RL. U.S. Diagnostic Reference Levels and Achievable Doses for 10 Adult CT Examinations. Radiology 2017;284:120-33.

17. Foley SJ, McEntee MF, Rainford LA. Establishment of CT diagnostic reference levels in Ireland. Br J Radiol 2012;85:1390-7. [CrossRef]

18. Kalra MK, Maher MM, Toth TL, Schmidt B, Westerman BL, Morgan HT, et al. Techniques and applications of automatic tube current modulation for CT. Radiology 2004;233:649-57. [CrossRef]

19. Federal Office for Radiation Protection. Notice of diagnostic reference levels for radiology and nuclear medicine examinations [Article in German]. Salzgitter: Federal Office for Radiation Protection; 2010.

20. Korir GK, Wambani JS, Korir IK, Tries MA, Boen PK. National diagnostic reference level initiative for computed tomography examinations in Kenya. Radiat Prot Dosimetry 2016;168:242-52.

21. Ekpo1 EU, Adejoh T, Akwo JD, Emeka OC, Modu AA, Abba M, et al. Diagnostic reference levels for common computed tomography (CT) examinations: results from the first Nigerian nationwide dose survey. J Radiol Prot 2018;38:525-35. [CrossRef]

22. Akpochafor MO, Omojola AD, Habeebu MY, Ezike JC, Adeneye SO, Ekpo ME, et al. Computed Tomography Organ Dose Determi- 
nation Using ImPACT Simulation Software: Our Findings In SouthWest Nigeria. EJMO 2018;2:165-72.

23. Cakmak ED, Tuncel N, Sindir B. Assessment of Organ Dose by Direct and Indirect Measurements for a Wide Bore X-Ray Computed Tomography Unit That Used in Radiotherapy. International Journal of Medical Physics, Clinical Engineering and Radiation Oncology 2015;4:132-42. [CrossRef]

24. Ngaile JE, Msaki PK. Estimation of patient organ doses from CT examinations in Tanzania. J Appl Clin Med Phys 2006;7:80- 94.

25. Shrimpton PC, Jones DG, Hillier MC. Survey of CT practice in the UK. Part 2: dosimetric aspects. NRPB-R249. London: HMSO; 1991.

26. Nishizawa K, Maruyama T, Takayama M, Okada M, Hachiya J, Furuya $Y$. Determinations of organ doses and effective dose equivalents from computed tomographic examination. Br J Radiol 1991;64:208. [CrossRef]

27. Osei EK, DarkoJ.A survey of organ equivalent and effective doses from diagnostic radiology procedures. ISRN Radiol 2012;2013:204346.

28. Clarke J, Cranley K, Robinson J, Smith PH, Workman A. Application of draft European Commission reference levels to a regional CT dose survey. Br J Radiol 2000;73:43-50. [CrossRef]

29. Tsai HY, Tung CJ, Yu CC, Tyan YS. Survey of computed tomography scanners in Taiwan: dose descriptors, dose guidance levels, and effective doses. Med Phys 2007;34:1234-43. [CrossRef]

30. Origgi D, Vigorito S, Villa G, Bellomi M, Tosi G. Survey of computed tomography techniques and absorbed dose in Italian hospitals: a comparison between two methods to estimate the dose-length product and the effective dose and to verify fulfilment of the diagnostic reference levels. Eur Radiol 2006;16:227-37. [CrossRef]

31. Aldrich JE, Bilawich AM, Mayo JR. Radiation doses to patients receiving computed tomography examinations in British Columbia. Can Assoc Radiol J 2006;57:79-85.

32. European Commission. Radiation protection 109. Guidance on diagnostic reference levels (DRLs) for medical exposures. Luxebburg: Directorate-General Environment, Nuclear Safety and Civil Protection; 1999. Available at: https://ec.europa.eu/energy/sites/ener/ files/documents/109_en.pdf. Accessed Jul 13, 2018.

33. Shrimpton PC, Hillier MC, Lewis MA, Dunn M. Doses from computed tomography examinations in the UK-2003 review. Tech Rep NRPB-W67. Chilton: NRPB; 2004.

\section{Kuzey ve Orta Nijerya'daki İki Hastanede CT-Expo Yazılımı Kullanılarak Hastaya Verilecek Dozun Hesaplanması}

Amaç: Simülasyon yazılımı bilgisayarlı tomografi (BT) incelemelerine dayanarak organa verilecek dozun hesaplanmasına yardımcı olmuştur. Bu çalışmanın amacı volüm BT doz indeksi (CTDI ${ }_{\text {vol }}$ ), doz süresi (DLP), organa verilen dozla etkili dozu saptamak için CT-Expo (Microsoft Corp., Redmond, WA, USA) yazılımını kullanmaktır.

Gereç ve Yöntem: Bir A ünitesinin BT'sinden (Toshiba Aquillion 16-kesitli BT tarayıcı [(Toshiba Corp., Tokyo, Japonya]) ve B ünitesinin BT'sinden (Philips Brilliance I6-kesitli BT tarayıcı (Koninklijke Philips N.V., Amsterdam, Hollanda) toplam I7I hastanın verileri elde edildi ve verilmiş dozu hesaplamak için CT-Expo hesap tablosu kullanıldı.

Bulgular: Çalışılan iki kuruluşta en sık kraniyal BT (\%64 oranında) taramaları kullanıldı. İki cihaz arasında BT parametrelerinden maksimum kilovoltaj $\left(k V_{p}\right)$ ve miliamper/saniye $(m A s)$ cinsinden elektrik akım şiddeti istatistiksel açıdan anlamlı farklılık gösterdi $(p<0.05)$. A ve $B$ olarak adlandırdığımız BT cihazları arasında volüm $B T C T D I_{v o l}$ açısından anlamlı bir farklılık yoktu $(p=0.199)$. Başka çalışmalara göre $A$ ve $B$ cihazlarının $\mathrm{CTDI}_{\text {vol }}$ ile doz ile süresi çarpımı arasında istatistiksel açıdan anlamlı farklılık yoktu $(p<0.05)$. Diğer çalışmalara göre batın için ortalama etkili doz (E) daha yüksek olmasına rağmen farklılık istatistiksel açıdan anlamlı değildi $(p<0.05)$. Ayrıca, BT cihazları $A$ ile $B$ arasında organa verilen dozda anlamlı bir farklılık görülmedi $(p=0.677)$. Diğer çalışmalarla karşılaştırıldığında organa verilen doz açısından anlamlı bir farklılık belirlenemedi $(p<0.05)$.

Sonuç: CT-Expo yazılımının sonuçlarıyla imPACT yazılımının (ImPACT scanner değerlendirme grubu, Londra, BK) sonuçları iyi bir uyum göstermiştir. B kodlu BT ünitesine göre A kodlu BT ünitesiyle hesaplanan CTDI ${ }_{\text {vol }}$ ve DLP arasında büyük farklılıklar vardı. Bu farklılık her iki tarayıcının kVp'si ve çözünürlük derecesinde saptanan anlamlı farklılık ile ilişkili olabilirdi.

Anahtar Sözcükler: Bilgisayarlı tomografi; bilgisayarlı tomografi volüm/doz indeksi; doz-süre çarpımı; etkili doz; organ dozu. 